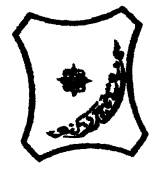

Bayero Journal of Pure and Applied Sciences, 11(1): 357 - 367

ISSN 2006 - 6996

\title{
SOME METAL(II) COMPLEXES OF A SCHIFF BASE. DERIVED FROM 2,3 DIAMINOPYRIDINE AND 2-HYDROXY -1- NAPHTHALDEHYDE
}

\author{
${ }^{1}$ Sani, U. and ${ }^{2}$ Lawal, M. A. \\ ${ }^{1}$ Department of Pure and Industrial Chemistry, Bayero University Kano, P.M.B 3011, Kano, Nigeria \\ ${ }^{2}$ Department of Chemistry, Federal College of Education, Zaria P.M.B 1041, Kaduna, Nigeria \\ Corresponding author: sumar.chm@buk.edu.ng; Tel.:+2348035370070
}

\section{ABSTRACT}

Schiff base derived from condensation of 2,3 diaminopyridine and 2-hydroxy -1naphthaldehyde and its $\mathrm{Mn}$ (II), Ni,(II) and $\mathrm{Cu}(\mathrm{II})$ complexes have been synthesized. The Schiff base and its complexes were characterized by solubility test, melting point/decomposition temperature determinations, molar conductance measurement, spectroscopic and magnetic susceptibility measurement, and gravimetric method of analysis. The ligand is dark green with melting point of $180^{\circ} \mathrm{C}$ and percentage yield of $81.86 \%$. The percentage yields of the complexes were in the range of $55.19-74.85 \%$, the decomposition temperatures of the complexes were in the range of $200-292{ }^{\circ} \mathrm{C}$. Their molar conductance values (4.84 - 13.36 $\mathrm{ohm}^{-1} \mathrm{~cm}^{2} \mathrm{~mol}^{-1}$ ) indicate that all the complexes are non-electrolytes. Magnetic moment values of the complexes showed that all are paramagnetic. A tetrahedral geometry was proposed for Mn(II) complex while square planar was proposed for Co(II) and Ni(II) complexes. The ligand and it's metal (II) complexes were screened for antibacterial and antifungal activities against some bacterial (Escherichia coli, Salmonella typhi, and Staphylococcus aureus) and fungal isolates (Aspergillus flavus, Aspergillus niger, Candida albican). The inhibition properties showed that the complexes have higher antimicrobial activity than the ligand which could be attributed to chelation, however lower than the standards used.

KEY WORDS: Schiff base, Transition metal complex, spectral study, gravimetric analysis, Antimicrobial study.

INTRODUCTION

Metal complex of Schiff base have played a central role in the development of coordination chemistry. Schiff base offer a versatile and flexible series of ligands capable of binding with various metal ions to give complexes with suitable properties for theoretical or practical applications (Sexana, 2013). The condensation reaction of primary amine with compounds containing a carbonyl group gives a Schiff base (Aliyu and Abdullahi, 2009). The common structural feature of these compounds is the azomethine group with a general formula (RHC $=\mathrm{N}-\mathrm{R}^{1}$ ) where $\mathrm{R} \& \mathrm{R}^{1}$ are alkyl, aryl cyclo or heterocyclic groups which may be variously substituted.

According to Akila et al. (2013) in recent decades, metallocomplexes have received much attention in chemistry, biochemistry, and pharmacy as promising compounds for the creation of novel drugs. On one hand, using such complexes, it is possible to avoid some negative effects inherent drug compositions containing inorganic salts, which can dissociate with the formation of metal ions. On the other hand, metal ions can modify both magnitude and direction of the pharmacological activity of the initial organic compound (Ligands) as a result of changes in the size, shape, charge density distribution, and redox potentials.

According to Gomathi and Ramu (2013) Schiff base ligands are potential anticancer, antibacterial agents and this activity tends to increase in metal (II) Schiff base complex. The co-workers were of the view that the infectivity of influenza A virus is reduced after exposure on copper surfaces. Copper (II) complex are regarded as the most promising alternatives to ciplastinas anticancer drugs; an idea supported by a considerable number of research articles describing the synthesis, DNA binding and cytotoxic activities of numerous copper (II) complexes.

Dinku et al. (2003) reported that the wide utilization of herbicides in crop management has created a challenging problem interms of residual herbicides and these are causing serious symptoms of illness in animal and human consumers. They come up with two approaches to this problem viz: (i) Derivatization of herbicides into less harmful compounds after crop development (ii) Metal ion associated degradation or deactivation of the herbicides. 
Special Conference Edition, November, 2018

The researchers claim to verify two approaches, they synthesized $\mathrm{Co}(\mathrm{II}), \mathrm{Ni}(\mathrm{II})$, and $\mathrm{Cu}$ (II) complexes of 2(2-hydroxyethyl hydrazine4-ethylamine-6-isopropylamine-S-triazine

(HEATZ), the derivative of Atrazine (ATZ). The antimicrobial studies of the ligand and the complexes against $E$. coli and $S$. aureus showed no any growth inhibitory activity against the two microbes the co-workers suggested the derivatization of ATZ to HEATZ and metal complex formation with $\mathrm{Co}(\mathrm{II}), \mathrm{Ni}(\mathrm{II})$ and $\mathrm{Cu}(\mathrm{II})$ as model to detoxify atrazine.

In this work, we report the synthesis, characterization and antimicrobial activity of a Schiff base and its metal two complexes Mn(II), $\mathrm{Ni}(\mathrm{II})$, and $\mathrm{Cu}$ (II) derived from condensation of 2 hydroxy-1-naphthaldehyde and 2, 3diaminopyridine. This is in furtherance of the above, and of the sustained interest in the utilization of the transition metal complexes in the treatment of human ailments, against the backdrop of the alarming problems of multidrug resistant microorganism, world over (Yiase et al., 2014).

\section{MATERIALS AND METHODS}

The reagents used were of analytical grade and used without further purification. All the glass wares were washed with detergent and dried in an oven at $110^{\circ} \mathrm{C}$ before use. The weighing was carried on electrical meter Toledo B154. The IR spectra were recorded using Fourier Transformed Infrared spectroscopy (FTIR CARY 630 Agilent Technology). The melting point and decomposition temperatures were determined using GallenKamp melting point apparatus. Magnetic susceptibility was determined using Sherwood MKI. The molar conductance measurement was carried out using Jenway 4010 model conductivity meter. The pathogenic isolates were collected from Aminu Kano Teaching Hospital and identified at the Department of Microbiology, Bayero University, Kano. Nutrient agar was used as bacteriological media while potato dextro agar was used as media for the fungal isolates.

\section{Preparation of Schiff base (Ligand)}

Ethanolic solution of 2,3-diaminopyridine $(0.02 \mathrm{~mol}, 2.1836 \mathrm{~g})$ was slowly added to ethanolic solution of 2-hydroxy-1naphthaldehyde $(0.02 \mathrm{~mol}, 3.4436 \mathrm{~g})$. The mixture was refluxed for 3hours and then allowed to cool to room temperature. The precipitate formed was filtered and washed with cold ethanol and dried over phosphorus pentaoxide (Aliyu and Sani 2011).

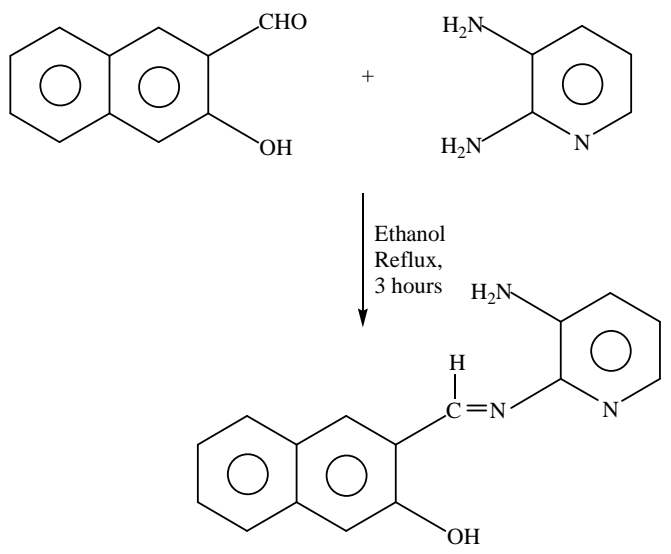

Scheme 1: Preparation of Schiff base

Preparation of metal (II) Schiff base complexes

Ethanolic solutions of metal chlorides (0.01 mol) were treated separately with ethanolic solution of the Schiff base in the ratio 1:2. The mixture was refluxed for 3 hours. The volume of the resulting solution was concentrated, by evaporating the solvent. The reaction mixture was cooled to room temperature. The precipitate was filtered, washed thoroughly with ethanol and dried over phosphorus pentaoxide (Aliyu and Sani 2011). 


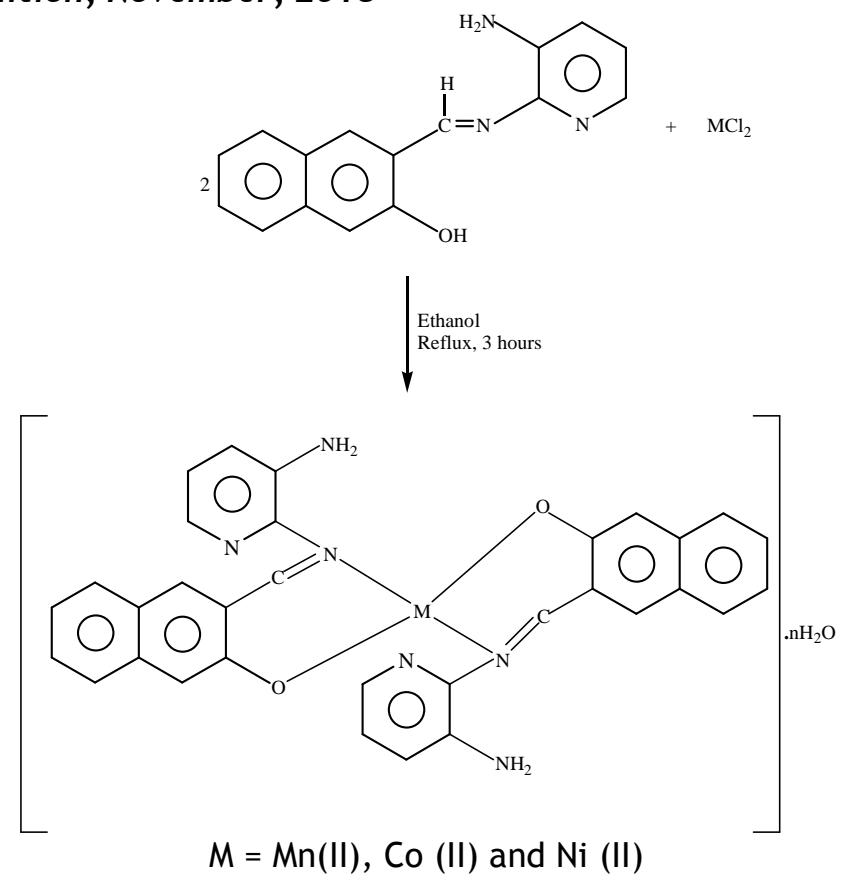

Scheme 2: Preparation of Complexes

\section{Magnetic Susceptibility Measurement}

Each of the complexes was introduced into a capillary tube. The height of the sample in the capillary tube was measured and recorded. The capillary tube was inserted into the machine and the reading was taken. From the readings obtained, the mass magnetic moment of the complexes was calculated using the relation: $\Psi_{\mathrm{g}}$ $=\frac{\mathrm{CL}\left(\mathrm{R}-\mathrm{R}_{\mathrm{o}}\right)}{10^{9} \mathrm{M}}$

Where $\Psi_{\mathrm{g}}=$ Mass magnetic moment fixed as 1

$\mathrm{C}=$ Constant of the machine and it is capillary tube

$L=$ Length of the sample in the sample

$\mathrm{R}=$ Specific magnetic moment of the

$\mathrm{R}_{\mathrm{o}}=$ Magnetic moment of the empty capillary tube

$$
M=w_{2}-w_{1}
$$

$W_{1}$ and $W_{2}$ are the weight of the empty capillary tube and capillary tube + complex respectively. Positive value of $\Psi_{\mathrm{g}}$ indicates a paramagnetic complex, while a negative value indicates a diamagnetic complex.

Molar magnetic moment of the complexes $\left(\Psi_{\mathrm{m}}\right)$ was determined by multiplying the mass magnetic moment of each complex with its molecular weight.

The effective magnetic moment $\left(\mu_{\text {eff }}\right)$ of the complexes were obtained from the relation

$\mu_{\text {eff }}=2.828 \sqrt{\left(\Psi_{\mathrm{m}} \times 298\right)}$

\section{Conductance measurement}

The conductivity was measured by immersing the electrode into $0.003 \mathrm{M}$ solutions of the complexes and the readings were taken. After each reading the electrode was rinsed with distilled water. The molar conductance of the complexes was calculated using the relation:

$$
\Lambda_{\mathrm{m}}=\frac{10^{3} \mathrm{~L}}{\mathrm{C}}
$$

Where $=$ molar conductance

$L=$ specific conductance of the complexes

\section{$C=$ concentrations}

\section{ESTIMATION OF METALS IN THE COMPLEXES} BY GRAVIMETRIC METHOD

Each of the complexes $(0.20 \mathrm{~g})$ was placed in a beaker containing $25 \mathrm{~cm}^{3}$ distilled water, $5 \mathrm{~cm}^{3}$ of concentrated nitric acid $\left(1.5 \mathrm{gcm}^{3}, 68 \% \mathrm{w} / \mathrm{w}\right)$ was added followed by vigorous stirring with a glass rod, the mixture was then heated on a hot plate to near dryness which was removed and cooled to room temperature. The mixture was then filtered and the filtrate was collected which contains the metal ions (Vogel, 1989).

\section{Determination of Manganese in Manganese (II)} complex

The filtrate was diluted to $100 \mathrm{~cm}^{3}$ with distilled water. Dilute ammonia was added to neutralize the filtrate followed by $10 \mathrm{~g}$ ammonium chloride, excess diammonium hydrogen phosphate $(\mathrm{NH} 4)_{2} \mathrm{HPO}_{4}$ and few drops of dilute hydrochloric acid. 
Special Conference Edition, November, 2018

The solution was heated to $95^{\circ} \mathrm{C}$ followed by drop wise addition of dilute aqueous ammonia with constant stirring until a precipitate of $\mathrm{Mn}_{3}\left(\mathrm{PO}_{4}\right)$ began to form. The addition of ammonia was stopped immediately while the heating and stirring continued to ensure that the precipitate formed crystallized as $\mathrm{MnNH}_{4} \mathrm{PO}_{4} \cdot \mathrm{H}_{2} \mathrm{O}$. Little aqueous ammonia was added with stirring until precipitation was completed. The precipitate was weighed as $\left[\mathrm{MnNH}_{4} \mathrm{PO}_{4} \cdot \mathrm{H}_{2} \mathrm{O}\right]$ (Vogel, 1989). The weight of the precipitate was used to calculate the percentage by weight of the manganese in the complexes by multiplying the weight of the precipitate with the gravimetric factor, where: Gravimetric factor of $\mathrm{Mn}$ in $\mathrm{Mn}$ (II) complexes =

Relative atomic mass of Manganese

Molecular weight of $\left[\mathrm{MnNH}_{4} \cdot \mathrm{PO}_{4} \cdot \mathrm{H}_{2} \mathrm{O}\right.$

Determination of Cobalt in Cobalt (II) Complex

A $0.7 \mathrm{~g}$ of ammoniumthiocynate was added to $80 \mathrm{~cm}^{3}$ of the filtrate and heated to boiling. $20 \mathrm{~cm}^{3}$ of pyridine was added after which heating was stopped immediately. The solution was stirred for 5 seconds and allowed to cool to room temperature. Red crystals of the precipitate were separated. The precipitate was filtered, washed, dried and weighed as dipyridinecobalt(II) $\left[\mathrm{Co}\left(\mathrm{C}_{5} \mathrm{H}_{5} \mathrm{~N}\right)_{2}\right](\mathrm{SCN})_{2}$ (Vogel, 1989).

The percentage composition by weight of cobalt in cobalt(II) complexes was calculated using gravimetric factor, where:

Gravimetric factor of Co inCo(II) complexes = Relative atomic mass of Cobalt

Molecular weight of $\left[\mathrm{Co}\left(\mathrm{C}_{5} \mathrm{H}_{5} \mathrm{~N}\right)_{2}\right](\mathrm{SCN})_{2}$

Determination of Nickel in Nickel (II) complex The filtrate of the nickel (II) complexes was diluted with $97 \mathrm{~cm}^{3}$ of distilled water. The mixture was heated to $70-80^{\circ} \mathrm{C}$ and alcoholic solution of $1 \%$ dimethylglyoxime (DMG) was added in slight excess, followed by immediate dropwise addition of dilute ammonia solution.

The content was allowed to cool and the precipitate separated, washed, dried at $110^{\circ} \mathrm{C}$ and weighed as [ $\left.\mathrm{Ni}\left(\mathrm{C}_{4} \mathrm{H}_{7} \mathrm{O}_{2} \mathrm{~N}_{2}\right)_{2}\right]$ (Vogel, 1989).

The percentage composition by weight of Nickel was calculated using gravimetric factor of Nickel.

Gravimetric factor of $\mathrm{Ni}$ in $\mathrm{Ni}(\mathrm{II})$ complexes =

Relative atomic mass of Nickel

Molecular weight of $\left[\mathrm{Ni}\left(\mathrm{C}_{4} \mathrm{H}_{7} \mathrm{O}_{2} \mathrm{~N}_{2}\right)_{2}\right]$
Determination of Water of Crystalliztion

$0.2 \mathrm{~g}$ of each complex was placed in a clean crucible of known weight. The crucible containing the complex was kept in an oven at $110^{\circ}$ Cuntil constant weight (Vogel, 1982). The percentage of water of crystallization in the complexes was calculated using the following equation

$\%$ of water of crystallization

$$
\begin{aligned}
& =\frac{\text { loss in mass }}{\text { mass of complex taken }} \\
& \times 100
\end{aligned}
$$

Antimicrobial Activity Test

The antibacterial and antifungal tests of the Schiff base and its metal complexes were carried out by agar well diffusion method. The bacterial isolates used in the screening are Escherichia coli, Salmonella typhi, and Staphylococcus aureus using nutrient $(\mathrm{NH})$ agar medium while for the fungal isolates Aspergillus niger, Aspergillus flavus and Candida albican. Potato dextro agar was used. Both medium were autoclaved at $121^{\circ} \mathrm{C}$ for 15 minutes. The medium were poured into a sterile petri-dish and were allowed to solidify. $0.06 \mathrm{~g}$ of each of the complexes and the ligand were dissolved in $1 \mathrm{ml}$ DMSO, preparation of the working solution was done by serial dilution. Three working concentration $(60,30$ and $15 \mu \mathrm{g} / \mathrm{ml}$ ) were prepared. $0.1 \mathrm{ml}$ of each of the concentration was added into the holes cut in solid medium nutrient agar and potato dextro agar inoculated with the tested and organisms and control at the centre. The plate were allowed to stay for pre-diffusion time and then incubated at 37 for 24 hours. The plates were removed from the incubator and the result was observed for the activity of the ligand and complexes against the tested isolates. The diameter of the zone of inhibition were measured with meter rule in $\mathrm{mm}$ (Yusha' $\mathrm{u}$ and Sadisu, 2011).

The standard used for the bacterial isolates was ceftrioxone $(50 \mathrm{mg} / \mathrm{ml})$ while that use for the fungal isolates was ketoconazole $(20 \mathrm{mg} / \mathrm{ml})$.

\section{RESULTS AND DISCUSSION}

The results of the characterization and antimicrobial activity of the synthesized Schiff base and its metal complexes are presented on the following tables 1, 2, 3, 4 and 5 respectively. 
Table 1: Analytical and Physical data for the Schiff base and its metal complexes

\begin{tabular}{|c|c|c|c|c|}
\hline $\begin{array}{l}\text { Compound } \\
\text { (Empirical } \\
\text { Formula) }\end{array}$ & $\mathrm{C}_{16} \mathrm{H}_{13} \mathrm{~N}_{3} \mathrm{O}$ & $\left.\mathrm{Mn}\left(\mathrm{C}_{16} \mathrm{H}_{13} \mathrm{~N}_{3} \mathrm{O}\right)_{2}\right] 3 \mathrm{H}_{2} \mathrm{O}$ & {$\left[\mathrm{Ni}\left(\mathrm{C}_{16} \mathrm{H}_{13} \mathrm{~N}_{3} \mathrm{O}\right)_{2}\right] 3 \mathrm{H}_{2} \mathrm{O}$} & {$\left[\mathrm{Cu}\left(\mathrm{C}_{16} \mathrm{H}_{13} \mathrm{~N}_{3} \mathrm{O}\right)_{2}\right] 2 \mathrm{H}_{2} \mathrm{O}$} \\
\hline $\begin{array}{l}\text { Calculated } \\
\text { formula weight } \\
\left(\mathrm{gmol}^{-1}\right)\end{array}$ & 263 & 635 & 639 & 621 \\
\hline Colour & $\begin{array}{l}\text { Light } \\
\text { green }\end{array}$ & Pale brown & Dark brown & Brown \\
\hline Yield (\%) & 81.86 & 61.97 & 74.85 & 55.19 \\
\hline $\begin{array}{l}\text { Metal found (Cal.) } \\
(\%)\end{array}$ & - & $8.85 \%$ (9.46\%) & $9.2 \%(10.08 \%)$ & $9.75 \%(10.08 \%)$ \\
\hline Melting Point $\left({ }^{\circ} \mathrm{C}\right)$ & 180 & - & - & - \\
\hline $\begin{array}{l}\text { Decomposition } \\
\text { Temperature }\left({ }^{\circ} \mathrm{C}\right)\end{array}$ & - & 290 & 292 & 200 \\
\hline B.M $\left(\mu_{\mathrm{eff}}\right)$ & - & 5.79 & 4.49 & 3.34 \\
\hline $\begin{array}{l}\text { Molarconductance } \\
\left(\mathrm{Ohm}^{-1} \mathrm{~cm}^{2} \mathrm{~mol}^{-1}\right)\end{array}$ & - & 4.84 & 3.35 & 13.66 \\
\hline
\end{tabular}

The condensation reaction between 2-hydroxy1-napthaldehyde and 2,3-diminopyridine yield a light green powder Schiff base with percentage yield of $81.86 \%$.

The metal (II) Schiff base complexes were synthesized and were found to be of varied colour; Mn(II) complex is pale brown $\mathrm{Ni}(\mathrm{II})$ complex is dark brown and $\mathrm{Cu}(\mathrm{II})$ complex is dark brown. These variation in colour between the ligand and complexes is an indication that complexation might have taken place, as the differences could be due to crystal field spitting of the d-orbitals of the transition metals due to chelation of the metal ions by the ligands and subsequently the electronic transition from $t_{2 g}$ to eg sub energy level, which is responsible for the absorption in the visible region of the electromagnetic spectrum. The complexes have decomposition temperature range of $200-292^{\circ} \mathrm{C}$, which is higher than the melting point of the Schiff base $180^{\circ} \mathrm{C}$ also indicating complexation might have taken place forming coordination compounds that are more thermally stable than the Schiff base (Table 1). The metal chelate solutions $3.0 \times 10^{-3}$ molar in DMF show low conductance values (3.35 - 13.66 $\mathrm{Ohm}^{-1} \mathrm{~cm}^{2} \mathrm{~mol}^{-1}$ ) suggesting their nonelectrolytic nature the molar conductance value indicate absence of ion, hence the complex might be neutral (Bello, 2016)

The magnetic moment value determined at room temperature are in the range 1.76-5.14BM (Table 1) and this result is in consistent with the number of unpaired electrons observed in the d-orbitals of these metals in the proposed structure (scheme 2)

The empirical formulae of the metal (II) complexes were determined from the percentage composition of metal (II) ions and the ligand. The result obtained suggested the general formula $M\left(C_{16} \mathrm{H}_{13} \mathrm{~N}_{3} \mathrm{O}\right)_{2}$ where $M=\mathrm{Mn}^{2+}$, $\mathrm{Ni}^{2+}$ or $\mathrm{Cu}^{2+}$ (Table 1)

Table 2: Solubility Test of Ligand and its metal (II) complexes

\begin{tabular}{lcccc}
\hline Compound & $\mathrm{C}_{16} \mathrm{H}_{13} \mathrm{~N}_{3} \mathrm{O}$ & {$\left[\mathrm{Mn}\left(\mathrm{C}_{16} \mathrm{H}_{13} \mathrm{~N}_{3} \mathrm{O}\right)_{2}\right] 3 \mathrm{H}_{2} \mathrm{O}$} & {$\left[\mathrm{Ni}\left(\mathrm{C}_{16} \mathrm{H}_{13} \mathrm{~N}_{3} \mathrm{O}\right)_{2}\right] 3 \mathrm{H}_{2} \mathrm{O}$} & {$\left[\mathrm{Cu}\left(\mathrm{C}_{16} \mathrm{H}_{13} \mathrm{~N}_{3} \mathrm{O}\right)_{2}\right] 2 \mathrm{H}_{2} \mathrm{O}$} \\
\hline $\mathrm{H}_{2} \mathrm{O}$ & $\mathrm{IS}$ & $\mathrm{S}$ & $\mathrm{S}$ & $\mathrm{IS}$ \\
$\mathrm{MeOH}$ & $\mathrm{SS}$ & $\mathrm{SS}$ & $\mathrm{SS}$ & $\mathrm{SS}$ \\
$\mathrm{EtOH}$ & $\mathrm{SS}$ & $\mathrm{SS}$ & $\mathrm{SS}$ & $\mathrm{SS}$ \\
$\mathrm{CHCl}{ }_{3}$ & $\mathrm{SS}$ & $\mathrm{SS}$ & $\mathrm{SS}$ & $\mathrm{SS}$ \\
$\mathrm{CCl}_{4}$ & $\mathrm{SS}$ & $\mathrm{SS}$ & $\mathrm{SS}$ & $\mathrm{SS}$ \\
Benzene & $\mathrm{SS}$ & $\mathrm{SS}$ & $\mathrm{SS}$ & $\mathrm{SS}$ \\
Acetone & $\mathrm{SS}$ & $\mathrm{SS}$ & $\mathrm{SS}$ & $\mathrm{SS}$ \\
Acetonitrile & $\mathrm{SS}$ & $\mathrm{SS}$ & $\mathrm{S}$ & $\mathrm{SS}$ \\
DMF & $\mathrm{S}$ & $\mathrm{S}$ & $\mathrm{S}$ & $\mathrm{S}$ \\
DMSO & $\mathrm{S}$ & $\mathrm{S}$ & $\mathrm{S}$ & \\
\hline
\end{tabular}

Key: $\mathrm{S}=$ Soluble, $\quad \mathrm{IS}=$ Insoluble, $\mathrm{SS}=$ Slightly Soluble, $\mathrm{DMF}=$ Dimethylformamide DMSO = Dimethylsulfoxide

The solubility tests of the Schiff base ligand and its metal (II) complexes revealed that they are all insoluble in distilled water, slightly soluble in methanol, ethanol, chloroform, tetrachloromethane, benzene, acetone and acetonitrile. However they were all found to be soluble DMF and DMSO (Table 2). 
Table 3: Infrared Spectral Data of the Ligand and it's Metal (II) complexes

\begin{tabular}{lccccc}
\hline Compound & $\mathbf{v}(\mathrm{C}=\mathrm{N}) \mathbf{c m}^{-1}$ & $\mathbf{v}(\mathbf{M}-\mathbf{N}) \mathbf{c m}^{-1}$ & $\mathbf{v}(\mathbf{M}-\mathrm{O}) \mathbf{c m}^{-1}$ & $\mathbf{v}(\mathbf{O}-\mathbf{H}) \mathbf{c m}^{-1}$ & $\mathbf{v}\left(\mathrm{H}_{2} \mathrm{O}\right) \mathbf{c m}^{-1}$ \\
\hline $\mathrm{C}_{16} \mathrm{H}_{13} \mathrm{~N}_{3} \mathrm{O}$ & 1607 & - & - & 3435 & - \\
{$\left[\mathrm{Mn}\left(\mathrm{C}_{16} \mathrm{H}_{13} \mathrm{~N}_{3} \mathrm{O}\right)_{2}\right] 3 \mathrm{H}_{2} \mathrm{O}$} & 1596 & 620 & 415 & - & 3044 \\
{$\left[\mathrm{Co}\left(\mathrm{C}_{16} \mathrm{H}_{13} \mathrm{~N}_{3} \mathrm{O}\right)_{2}\right] 3 \mathrm{H}_{2} \mathrm{O}$} & 1603 & 665 & 430 & - & 3033 \\
{$\left[\mathrm{Ni}\left(\mathrm{C}_{16} \mathrm{H}_{13} \mathrm{~N}_{3} \mathrm{O}\right)_{2}\right] 2 \mathrm{H}_{2} \mathrm{O}$} & 1603 & 668 & 422 & - & 3052 \\
\hline
\end{tabular}

The nature and possible mode of bonding of the ligand with different metal ion have been studied by comparing the IR spectra of the ligand and that of the complexes.

The bands at $1607 \mathrm{~cm}^{-1}$ and $3435 \mathrm{~cm}^{-1}$ in the spectrum of the ligand were assigned to $v(\mathrm{C}=\mathrm{N})$ and $v(\mathrm{O}-\mathrm{H})$ of aromatic respectively. The $v(\mathrm{C}=\mathrm{N})$ band was observed in the in the range of 1603-1588 $\mathrm{cm}^{-1}$ evidence of nitrogen coordination of the azomethine nitrogen, the
$v(C=N)$ group to the central atom from the Shift of the frequency (Aliyu and Abdullahi, 2009).

This is supported by the appearance of new bands in the range of $620-668 \mathrm{~cm}^{-1}$ which are assigned to $v(M-N)$ stretching frequency. The band due to $v(M-O)$ stretching vibration is observed at $415-426 \mathrm{~cm}^{-1}$ which support the involvement of oxygen atom in coordination(Table 3) (Aliyu and Abdullahi, 2009).

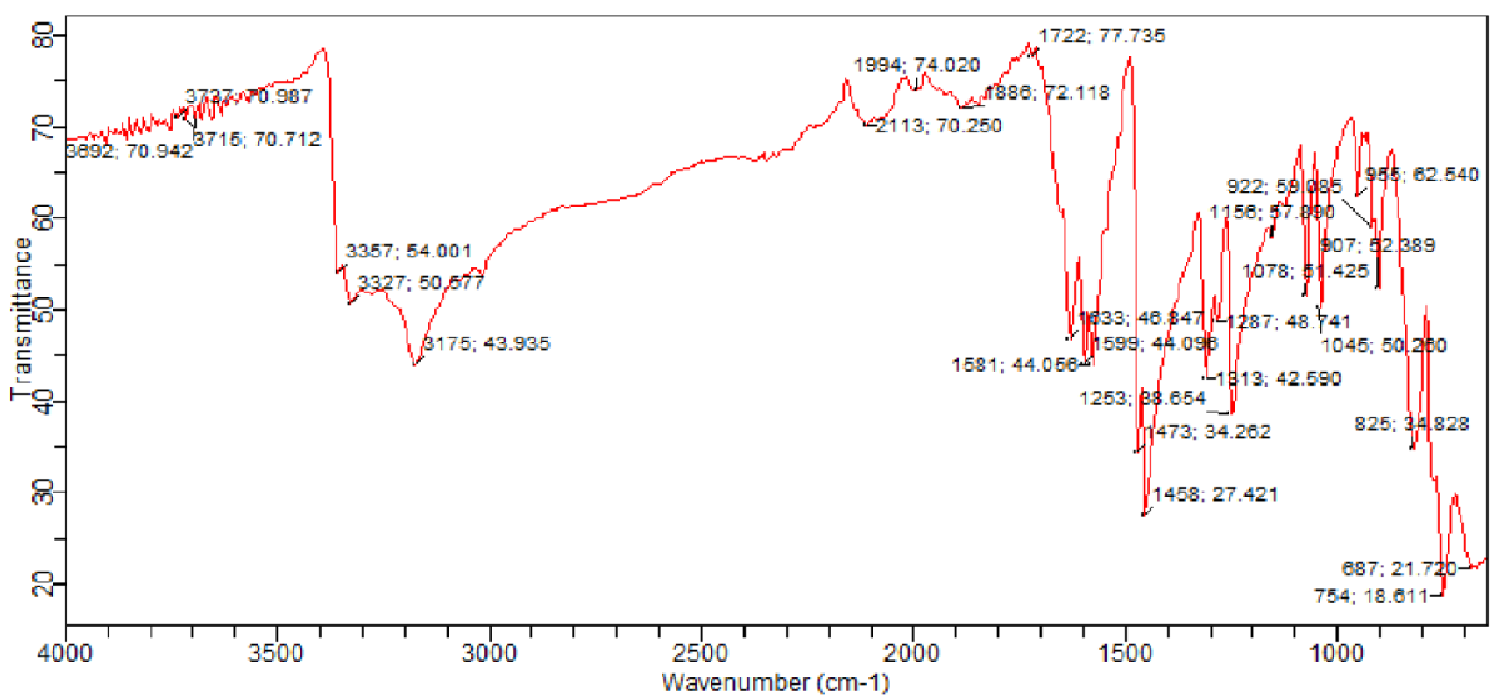

Fig. 1: 2,3-Diaminopyridine

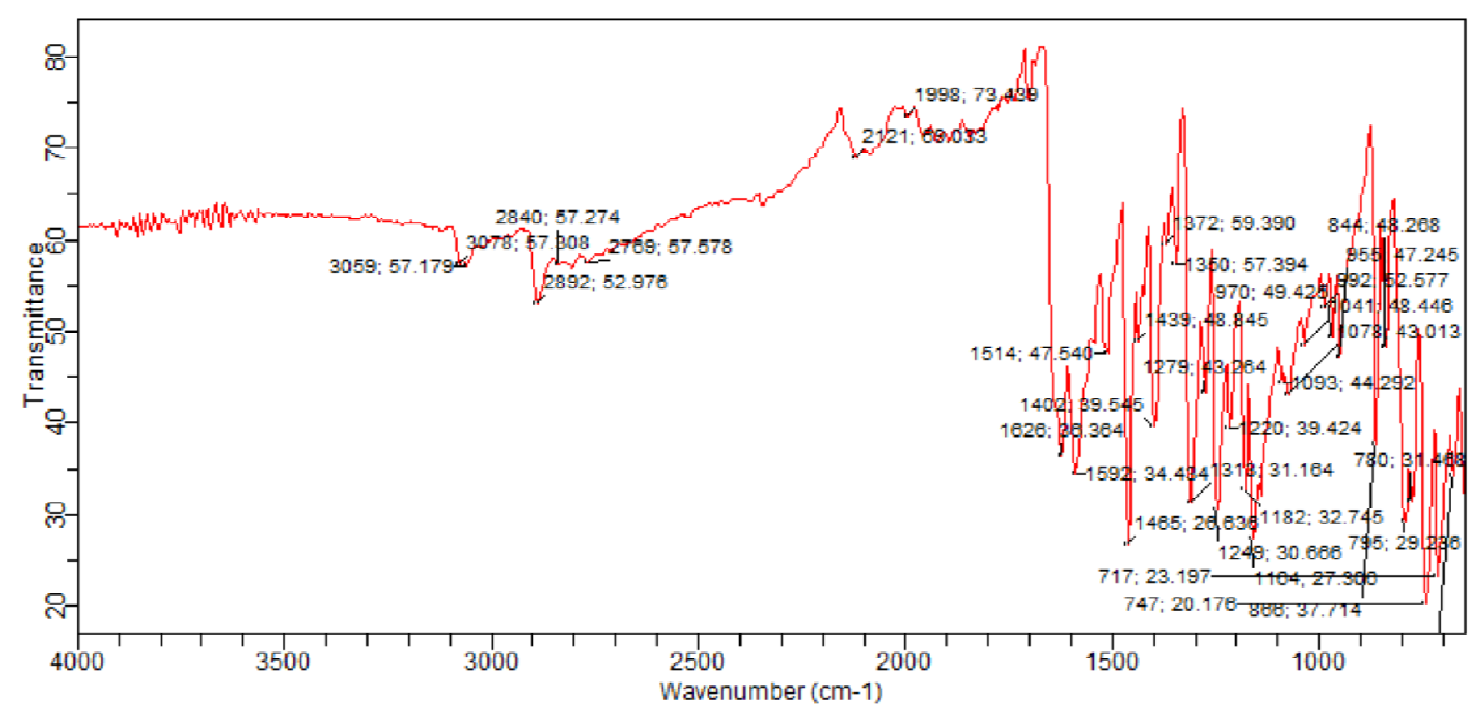

Fig. 2: 2-hydroxy-1-naphthadehyde 
Special Conference Edition, November, 2018

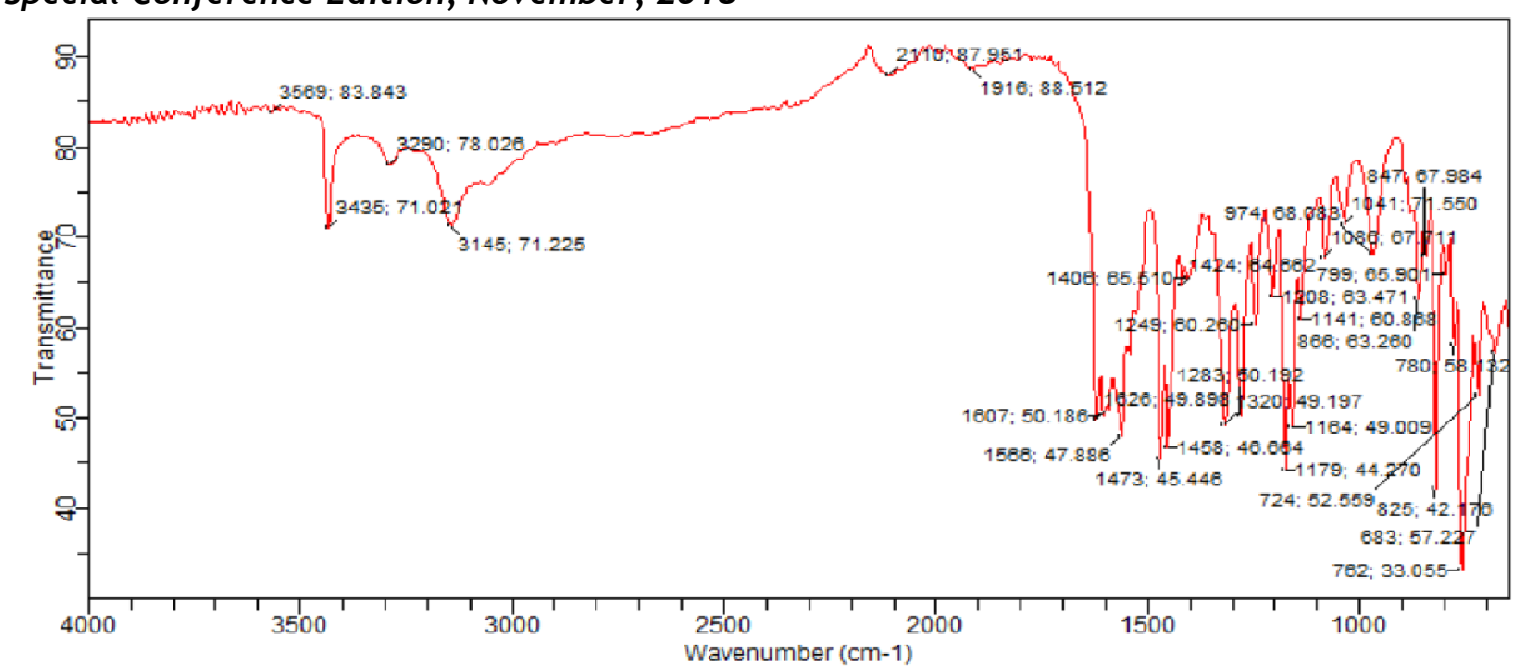

Fig. 3: Schiff Base
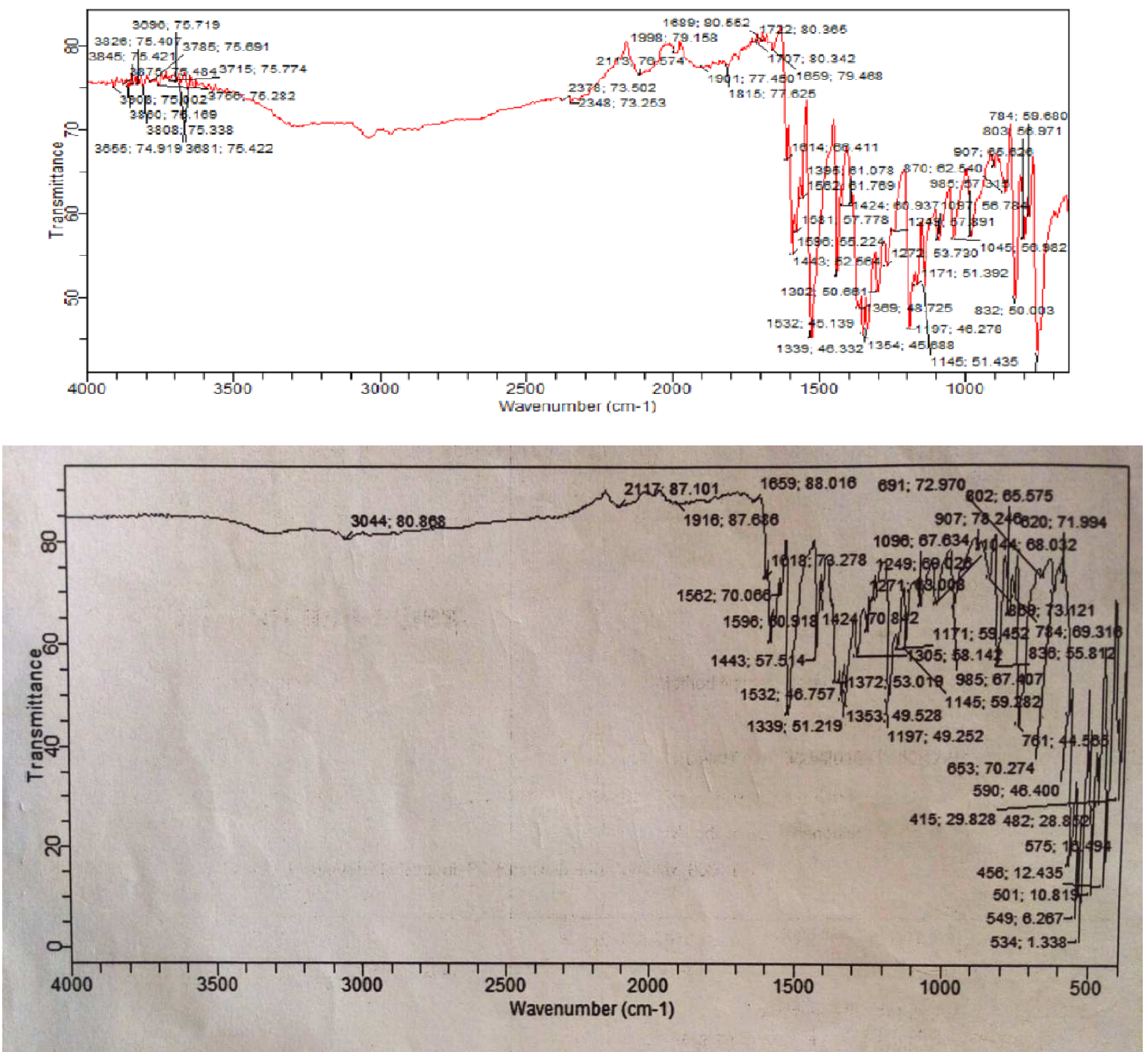

Fig. 4: Manganese complex 

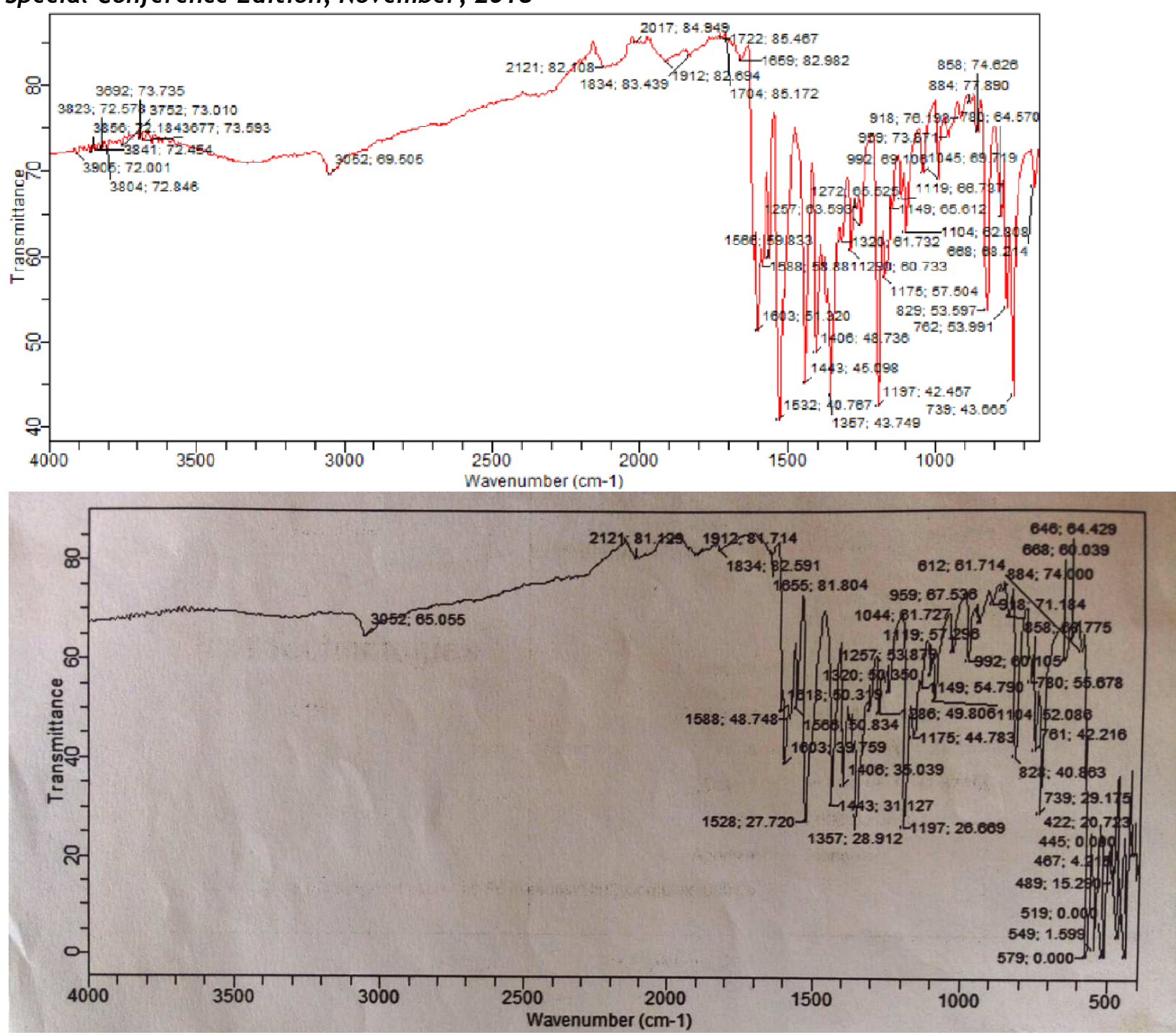

Fig 5: Nickel Complex

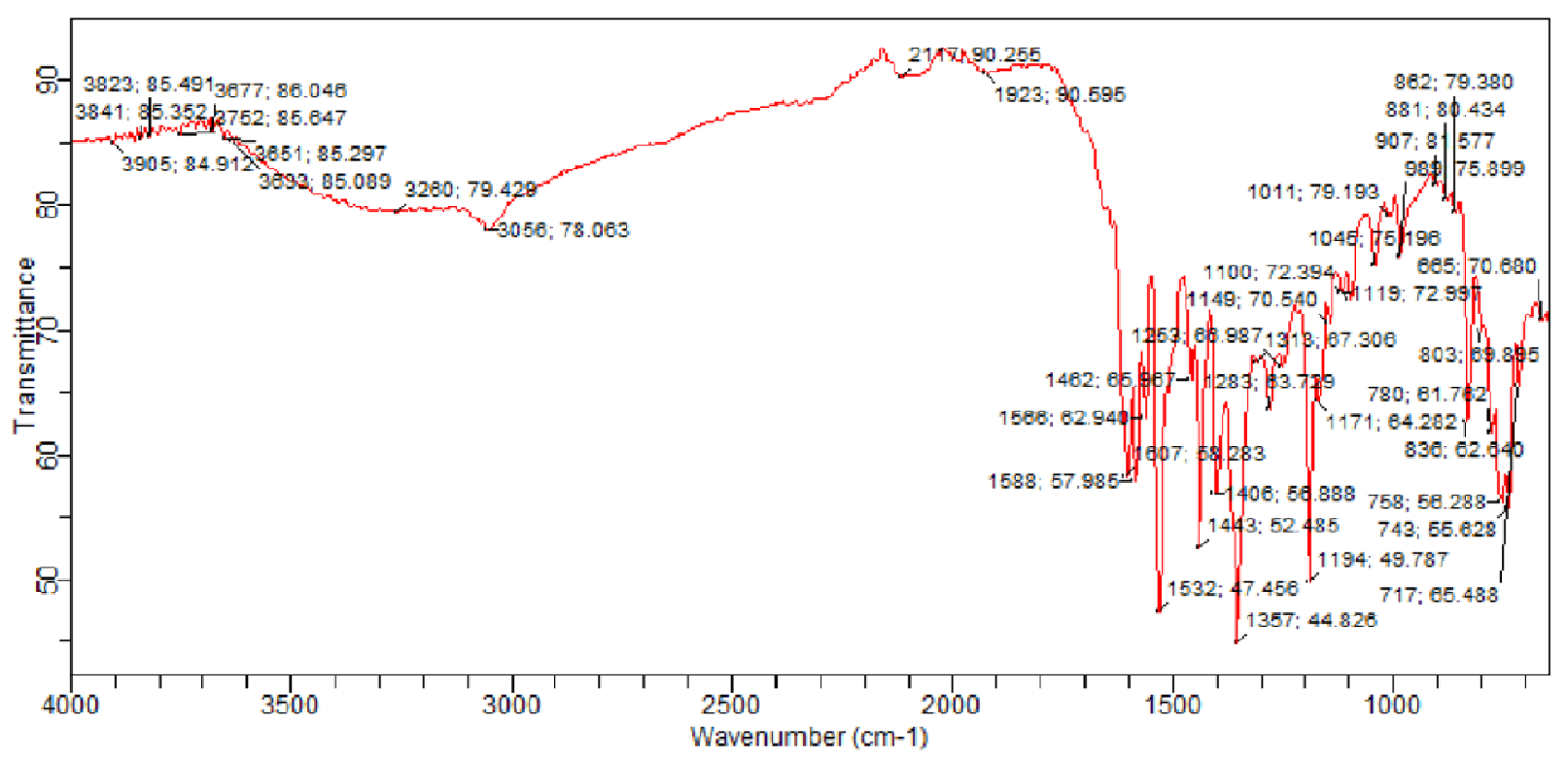




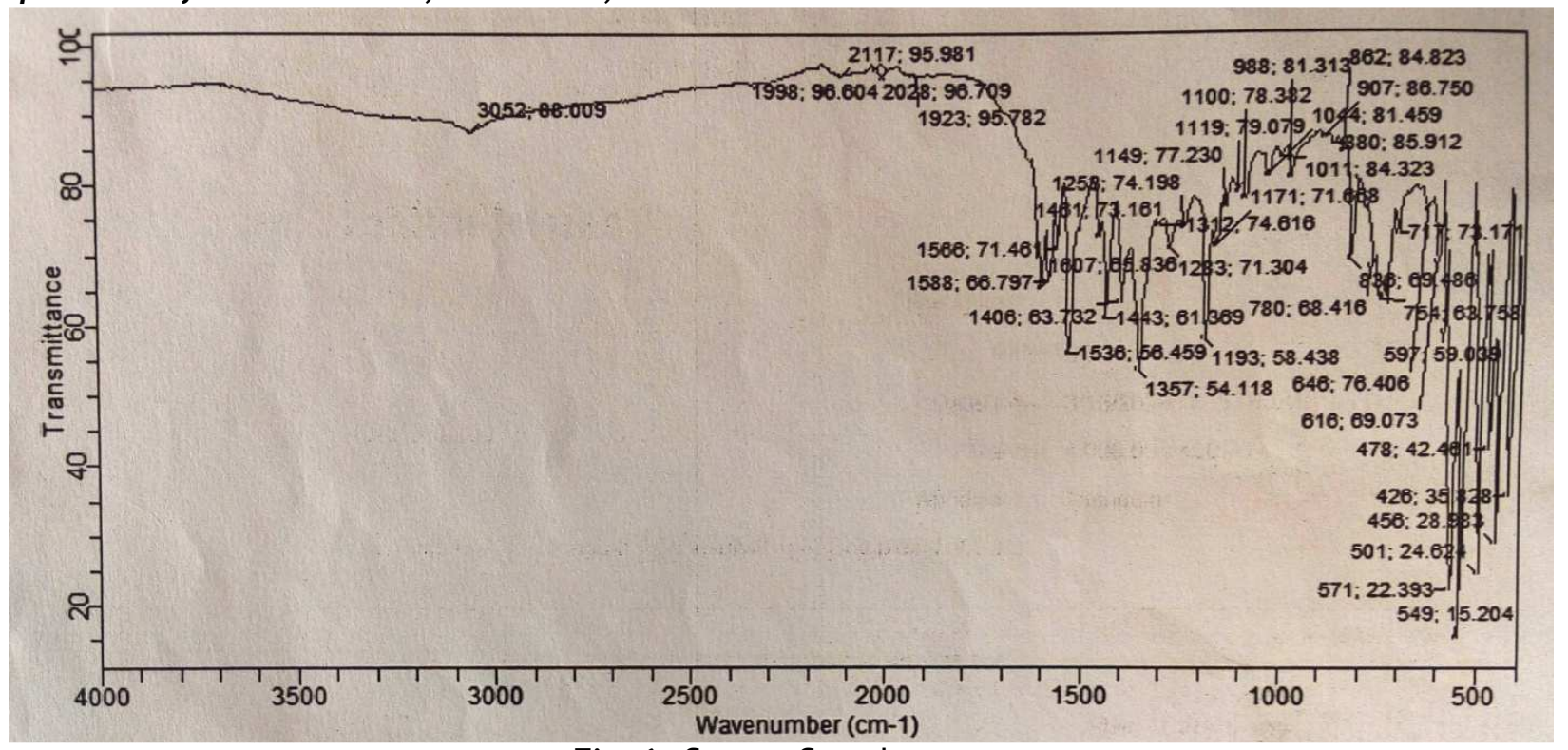

Fig. 6: Copper Complex

Table: 4: Determination of Water of Crystallization

\begin{tabular}{lcccc}
\hline Compound & Initial mass (g) & Final mass (g) & Loss mass (g) & \% of water \\
\hline$\left[\mathrm{Mn}\left(\mathrm{C}_{16} \mathrm{H}_{13} \mathrm{~N}_{3} \mathrm{O}\right)_{2}\right] 3 \mathrm{H}_{2} \mathrm{O}$ & 0.2 & 0.182 & 0.018 & 9.0 \\
{$\left[\mathrm{Co}\left(\mathrm{C}_{16} \mathrm{H}_{13} \mathrm{~N}_{3} \mathrm{O}\right)_{2}\right] 3 \mathrm{H}_{2} \mathrm{O}$} & 0.2 & 0.181 & 0.019 & 9.5 \\
{$\left[\mathrm{Ni}\left(\mathrm{C}_{16} \mathrm{H}_{13} \mathrm{~N}_{3} \mathrm{O}\right)_{2}\right] 2 \mathrm{H}_{2} \mathrm{O}$} & 0.2 & 0.187 & 0.013 & 6.5 \\
\hline
\end{tabular}

The percentage of water of crystallization in the complexes was determined and the result showed $\mathrm{Mn}$ (II), $\mathrm{Co}$ (II) and $\mathrm{Ni}$ (II) of complexes contained 9.0\%, 9.5\% and 6.5\% water respectively (Table 4).

Table 5: Antibacterial and Antifungal activity Inhibition zones of the ligand and its complexes

\begin{tabular}{|c|c|c|c|c|c|c|c|c|c|c|}
\hline Bacterial Isolate & \multicolumn{3}{|c|}{$\begin{array}{l}\text { Escherichia } \\
\text { coli }\end{array}$} & \multicolumn{3}{|c|}{$\begin{array}{l}\text { Salmonella } \\
\text { typhi }\end{array}$} & \multicolumn{3}{|c|}{$\begin{array}{l}\text { Staphylococcus } \\
\text { aureus }\end{array}$} & \multirow[t]{2}{*}{$\begin{array}{l}\text { Control (Cettriaxone) } \\
(50 \mathrm{mg} / \mathrm{ml})\end{array}$} \\
\hline $\begin{array}{l}\text { Concentration } \\
(\mu \mathrm{g} / \mathrm{ml})\end{array}$ & 60 & 30 & 15 & 60 & 30 & 15 & 60 & 30 & 15 & \\
\hline $\mathrm{C}_{16} \mathrm{H}_{13} \mathrm{~N}_{3} \mathrm{O}$ & 17 & 14 & 13 & 10 & 8 & 6 & 12 & 12 & 11 & \\
\hline$\left[\mathrm{Mn}\left(\mathrm{C}_{16} \mathrm{H}_{13} \mathrm{~N}_{3} \mathrm{O}\right)_{2}\right] 3 \mathrm{H}_{2} \mathrm{O}$ & 14 & 10 & 8 & - & - & - & 10 & 8 & 8 & 46 \\
\hline$\left[\mathrm{Ni}\left(\mathrm{C}_{16} \mathrm{H}_{13} \mathrm{~N}_{3} \mathrm{O}\right)_{2}\right] 3 \mathrm{H}_{2} \mathrm{O}$ & 17 & 15 & 13 & & & & 17 & 15 & 13 & \\
\hline$\left[\mathrm{Cu}\left(\mathrm{C}_{16} \mathrm{H}_{13} \mathrm{~N}_{3} \mathrm{O}\right)_{2}\right] 2 \mathrm{H}_{2} \mathrm{O}$ & 16 & 12 & 10 & 20 & 17 & 14 & 21 & 17 & 15 & \\
\hline Fungal Isolate & \multicolumn{3}{|c|}{$\begin{array}{l}\text { Aspergillus } \\
\text { flavus }\end{array}$} & \multicolumn{3}{|c|}{$\begin{array}{l}\text { Aspergillus } \\
\text { niger }\end{array}$} & \multicolumn{3}{|c|}{ Candida albican } & $\begin{array}{c}\text { Control (Ketoconazole) } \\
(20 \mathrm{mg} / \mathrm{ml})\end{array}$ \\
\hline $\begin{array}{l}\text { Concentration } \\
(\mu \mathrm{g} / \mathrm{ml})\end{array}$ & 60 & 30 & 15 & 60 & 30 & 15 & 60 & 30 & 15 & \\
\hline $\mathrm{C}_{16} \mathrm{H}_{13} \mathrm{~N}_{3} \mathrm{O}$ & - & - & - & 17 & 14 & 12 & 10 & 8 & 6 & \\
\hline$\left[\mathrm{Mn}\left(\mathrm{C}_{16} \mathrm{H}_{13} \mathrm{~N}_{3} \mathrm{O}\right)_{2}\right] 3 \mathrm{H}_{2} \mathrm{O}$ & 14 & 10 & 8 & 12 & 11 & 9 & - & . & - & 27 \\
\hline$\left[\mathrm{Ni}\left(\mathrm{C}_{16} \mathrm{H}_{13} \mathrm{~N}_{3} \mathrm{O}\right)_{2}\right] 3 \mathrm{H}_{2} \mathrm{O}$ & - & - & - & 10 & 8 & 7 & 10 & 8 & 7 & \\
\hline$\left[\mathrm{Cu}\left(\mathrm{C}_{16} \mathrm{H}_{13} \mathrm{~N}_{3} \mathrm{O}\right)_{2}\right] 2 \mathrm{H}_{2} \mathrm{O}$ & 20 & 14 & 12 & 17 & 15 & 14 & 17 & 16 & 14 & \\
\hline
\end{tabular}

The inhibition zones of the antimicrobial screening of the Schiff base and its metal complexes were measured in $\mathrm{mm}$ and results are shown on Table 5 . The Schiff base and the complexes show significance activity against the bacterial isolates but $\mathrm{Mn}$ (II) and $\mathrm{Ni}(\mathrm{II})$ complex were inactive against Salmonella typhi. Cu(II) complex was found to be more active against all tested bacterial isolates.Studies on the fungal activity showed that the ligand and $\mathrm{Ni}(\mathrm{II})$ complex have strong activity against Aspergillus niger, both were inactive against Aspergillus flavus while $\mathrm{Cu}(\mathrm{II})$ show relatively high activity for all tested isolates. Both the antibacterial and antifungal activity of these compounds show ascending order, when the concentration increase, area of inhibited growth also increased. Generally the complexes are more active than the free ligand and less than the standards used.

Based on the results obtained from the tables above, the proposed structure of the synthesized Schiff base and the complexes are as follows: 


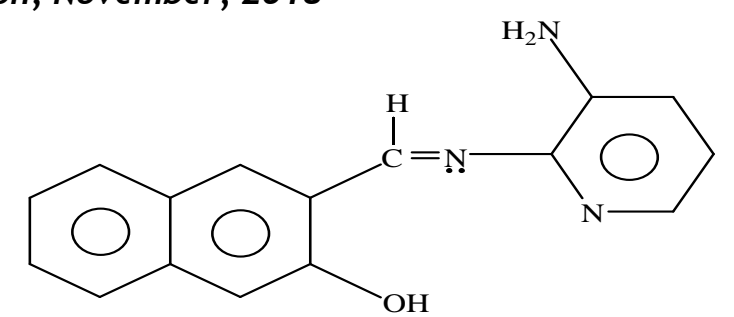

Scheme 1: Proposed structure of the Schiff base

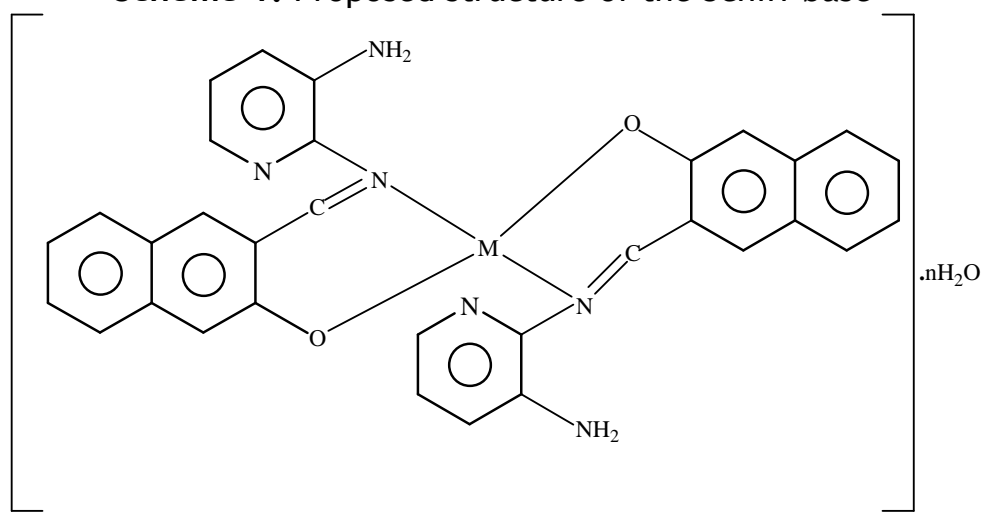

$\mathrm{M}=\mathrm{Mn}(\mathrm{II}), \mathrm{Ni}$ (II) and $\mathrm{Cu}$ (II)

Scheme 2: Proposed structure of the Complexes

\section{CONCLUSION}

Based on physicochemical and spectral data it is concluded that the Schiff base and its metal complexes were successfully synthesized employing imino nitrogen and phenolic oxygen in bonding. The complexes were found to be neutral as revealed by the molar conductance data. The magnetic moment suggest tetrahedral geometry for the $\mathrm{Mn}$ (II) and $\mathrm{Co}$ (II) complexes, and square planar for $\mathrm{Ni}(\mathrm{II})$ complex (Scheme 1 and 2). The complexes are biologically active against some of the tested isolates and show enhanced antimicrobial activities compared to free ligand

\section{REFERENCES}

Akila E, Usharani M. and Ravel R. (2013). Metal (II) complexes of bioinorganic and medicinal relevance, antibacterial, antioxidant and DNA cleavage studies of tetradentate complexes involving $\mathrm{O}, \mathrm{N}$ donor envt of 3, 3' -dihydroxybenzidinebased Schiff base. International Journal of Pharmacy and Pharmaceutical Science.

Aliyu, H. N. and Abdullahi H. J. (2009). Synthesis and characterization of Maganese(II), Cobalt(II), Nickel(II) and copper(II) N, $\mathrm{N}^{1}$-Bis (Benzoin) Ethylenediiminato complexes. Bjopas 2(2):110-112.

Aliyu, H., N., and Sani, U. (2011). Synthesis, Antibacterial and Antifungal Investigation of $\mathrm{Mn}$ (II) complexes with Schiff Base Derived from 2-hydroxy-1- as such they may be used for formulating novel medicinal and chemotherapeutic agents.

\section{RECOMMENDATIONS}

$>$ Other spectroscopic analyses such as ${ }^{13} \mathrm{C}$ NMR, ${ }^{1} \mathrm{H}$ NMR and MS should be carried out to further confirm the structure of the synthesized complexes.

$>\quad$ X-ray powder diffraction analysis should be done on these compounds to ascertain the exact positions, bond lengths as well as bond angles between the atoms

$>$ Toxicity studies should be conducted to study the effect of the synthesize compounds on living organisms.

naphthaldehyde and some alphatic diamines. Bayero Journal of Pure and Applied Sciences, 4(1):83-87.

Bello, J. (2016). Synthesis Characterization and Antimicrobial Studies on Bis[(2Z)-2-(2hydroxy-3H-Indole-3-ylidene)

hydrazine-1-carbothioamido] hydrate metal (II) complexes. An unpublished M.Sc thesis submitted to the Department of Pure and Industrial Chemistry, Bayero University Kano.

Dinku, W., Megersa, N., Raju. V. J., Solmon, T., Jonsson, J. K. and Retta, N. (2003). Studies on transition metal complex of herbicidal compounds: Transition metal complex of Derivatized 2-chloro-4ethyl-amino-6-isopropylamino-striazine(ATRAZINE). Bull. Chemical Society of Ethiopia, 7(1)35-43. 
Gomathi, R. and Ramu, A. (2013). Synthesis Characterization of novel $\mathrm{Cu}(\mathrm{II})$ complexes of Isatin derivatives as potential cytotoxicity, DNA bind, cleavage and antibacterial agent. International Journal of Innovative Research in Science, Engineering and Technology, 2(9):2319-8753.

Sexana, A. (2013). Synthesis and Characterization of Schiff base salicaldehyde and thiohydrazone and its metal complexes. Pelagia Research Library. Advances in Applied Science Research, 4(4):152-154.
Vogel, T. (1989). Practical Inorganic Chemistry, $4^{\text {th }}$ edition, Jhon Wiley Inc. England: 133-325.

Yiase, S. G., Adejo, S. O., Gbertyo, J. A. and Ede. J. (2014). Synthesis Characterization and antimicrobial studies of salicylic acid complex of some transition metals. Journal of Applied Chemistry, 7(4):4-10.

Yusha'u M. and Sadisu F. U. (2011). Inhibition activity of deuterium microcarpum extracts on some clinical isolates: Biological and Environmental Science Journal for the Tropics 8(4): 113-117. 